\title{
In-vitro evaluation of antimicrobial activity of Dhupana drugs on Staphylococcus aureus
}

\author{
Research Article
}

\author{
Manita Ahlawat ${ }^{*}$, Reetu Sharma ${ }^{2}$, Mandal SK $^{3}$
}

1. PG Scholar, 2. Assistant Professor, 3. Associate Professor, Department of Roga \& Vikriti Vijnana, National Institute of Ayurveda, Jaipur

\begin{abstract}
Multidrug resistance in the notorious bacterial strains is accounting for a tremendous increase in global mortality rate. The upcoming new generation antibiotics are granting a perceptive provision in this issue but the superbugs have enforced these antimicrobial agents to surrender by developing the innovative variation in their genes/ plasmids. So alternatives are desired to combat this problem. Herbal drugs may broaden this spectrum of antimicrobial agents by offering safer and promising approach. Dhupana karma is such a modality known for its antimicrobial activity due to its indication in infectious diseases as per classical texts. The present study included fumigation on Staphyloccus aureus with four Dhupana formulations to assess their antimicrobial activity. The assessment criteria taken was mean bacterial colony count after $20 \mathrm{~min}$ of fumigation compared with control (without fumigation). Statistical analysis was done using Anova test and Tukey Kramer comparison test. The \% change in mean colony count of B1 (S.aureus) after 20 min of fumigation was found to be $76.61 \%$ with drug D1 (Nimbadi Dhupa), $84.13 \%$ with drug D2 (Kumaragara Dhupa), $80.51 \%$ with drug D3 (Dashanga Dhupa) and $98.94 \%$ with drug D4 (Gana Dhupa).
\end{abstract}

Keywords: Multidrug resistance, Dhupana karma, Antimicrobial agents.

\section{Introduction}

The effective prevention and treatment of an ever -increasing range of infections caused by bacteria, parasites, viruses and fungi is constantly being threatened by increasing antimicrobial resistance. It is a complex global public health challenge and is accelerated by the misuse of antimicrobial agents. The increasing waves of antibiotic resistance in $S$. aureus set a problematic example of this issue. Today, $S$. aureus is a growing issue both within hospitals and communities because of its internal virulence and ability to adjust to different environments. Despite the availability of effective antimicrobials, the mortality of $S$. aureus bacteraemia remains approximately 20 $40 \%$ (1).

The upcoming antimicrobial drugs are becoming less effective or even ineffective resulting in global health security emergency that is rapidly beating the available treatment options. It is posing a great impact on particularly vulnerable and immunocompromised patients resulting in prolonged illness, life threatening infections acquired in hospitals and in the community and finally increased mortality. It causes the crucial necessity for development and implementation of

*Corresponding Author:

\section{Manita Ahlawat}

PG Scholar,

Department of Roga \& Vikriti Vijnana,

National Institute of Ayurveda, Jaipur

Email id: dr.ahlawatmanita16@gmail.com effective strategies to curtail the emergence and spread of AMR.

Herbal therapies and drugs may contribute in this field. Ayurveda is rich in treatment modalities in the context of microbiology. Although under noticed, these can be used as add on therapy along with modern antibiotics. Dhupana karma, a traditional method of sterilisation, can be a boon and help in curtailing the problem of increasing trends of antimicrobial resistance. It is a technique of delivering the plant active constituents in form of fumes to the target sites.

In the present study, four Dhupana formulations were assessed in vitro for their antimicrobial activity on S.aureus.

\section{Materials and methods}

Dhupana drugs

The drug formulations were prepared at NIA Pharmacy under expert's supervision. The required drugs were taken in raw form and then air dried. The drugs were ground into coarse powder using pulveriser machine and mixed in equal proportions accordingly. The formulations were then stored in air tight containers at room temperature. Table 1 . shows the ingredients of the respective 4 formulations.

\section{Microorganism}

The isolated strain of Staphylococcus aureus (ATCC 29213) purchased from Hi media Laboratories Pvt. Ltd. Mumbai was selected for the study. The bacteria was cultured on Mueller Hinton Agar at $37^{\circ} \mathrm{C}$ for $24 \mathrm{~h}$ and then used for antimicrobial activity. 
Table 1: Showing the ingredients of four formulations

\begin{tabular}{|c|l|l|l|}
\hline S.No. & \multicolumn{1}{|c|}{ Drug } & \multicolumn{1}{|c|}{ Contents } & \multicolumn{1}{c|}{ Indication } \\
\hline D1. & Nimbadi Dhupa (2) & $\begin{array}{l}\text { Neem, Vacha, Kutha, Haritaki, Sarshapa, } \\
\text { Guggulu, Ghrita }\end{array}$ & Jvara \\
\hline D2. & $\begin{array}{l}\text { Kumaragara Dhupa } \\
(3)\end{array}$ & $\begin{array}{l}\text { Yava, Sarshapa, Atasi, Hingu, Guggulu, Vacha, } \\
\text { Choraka, Brahmi, Jatamansi, Ashoka, Rohini, } \\
\text { Sarpnirmoka } \text { (shedded snake skin), Ghrita }\end{array}$ & $\begin{array}{l}\text { Kumaragara } \\
\text { Dhupana }\end{array}$ \\
\hline D3. & Dashanga Dhupa (4) & $\begin{array}{l}\text { Sarshapa, Kuth, Bhallataka, Vacha, Bastaloma, } \\
\text { Tagara, Bhurjapatra, Guggulu, Ghrita }\end{array}$ & Sarvaroga \\
\hline D4. & Gana Dhupa (5) & $\begin{array}{l}\text { Akshat (rice), Jaatipushpa, Madhu, Sarshapa, } \\
\text { Vacha }\end{array}$ & Sarvabhutaruja \\
\hline
\end{tabular}

Fumigation chamber

A closed glass chamber $(11 \mathrm{~cm} \times 12 \mathrm{~cm} \times 13 \mathrm{~cm})$ was designed with a cover lid having a hole for entry of fumes into the chamber. The fumes were produced by burning powdered drugs over the hot plate with an inverted earthen funnel over it and were projected into the chamber through a rubber pipe connected with the funnel. Same set was designed for the control group (I), but no fumigation was done and thus it acted as negative control. A thick thermocol sheet was placed in between the chamber and the hot plate so as to nullify the direct effect of temperature by adjacent hot plate.

\section{Antimicrobial activity procedure}

In-vitro antibacterial activity was tested by fumigating the trial bacterial strain with the Dhupana drugs for a fixed duration. Each set of experiment was done in triplets as per the procedure. 3 swabs were dipped in bacterial suspension in test tube. 2 were put in fumigation chamber and one was taken in control chamber. Fumigation was done with fixed concentration of fumes obtained by burning Dhupana drugs on hot plate (5gm powder/ $5 \mathrm{~min}$ ) and projected to the swabs in the chamber for $10 \mathrm{~min}$ and $20 \mathrm{~min}$. The first and second swabs were taken outside after 10 min and $20 \mathrm{~min}$ of fumigation respectively and all the three swabs were diluted in $(3 \mathrm{ml})$ fresh peptone water separately. Inoculation was done on culture plates using loop method and the plates were incubated for $24 \mathrm{hrs}$. Bacterial colonies were counted and compared.

Observations and Results

Table 2. Showing the effect of D1 (Nimbadi Dhupa), D2 (Kumaragara Dhupa), D3 (Dashanga Dhupa) \& D4 (Gana Dhupa) on mean colony count of B1 (S.aureus) after fumigation for 20 min. C20 : bacterial colony count of control group (no fumigation) after $20 \mathrm{~min}$. F20 : bacterial colony count of trial group (fumigation done) after $20 \mathrm{~min}$.

\begin{tabular}{|c|c|c|c|c|c|c|}
\hline $\begin{array}{c}\text { B1 } \\
\text { (Bacterial strain 1) } \\
\text { (S.aureus) }\end{array}$ & $\mathbf{C 2 0}$ & F20 & $\begin{array}{l}\text { Difference in colony } \\
\text { count after 20 min } \\
(\text { C20-F20) }\end{array}$ & Mean & S.D & SEM \\
\hline \multirow[t]{3}{*}{ D1 } & 209 & 34 & 175 & \multirow{3}{*}{213.00} & \multirow{3}{*}{41.940} & \multirow{3}{*}{24.214} \\
\hline & 380 & 122 & 258 & & & \\
\hline & 245 & 39 & 206 & & & \\
\hline \multirow[t]{3}{*}{$\overline{D 2}$} & 289 & 03 & 286 & \multirow{3}{*}{302.33} & \multirow{3}{*}{16.503} & \multirow{3}{*}{9.528} \\
\hline & 415 & 96 & 319 & & & \\
\hline & 374 & 72 & 302 & & & \\
\hline \multirow[t]{3}{*}{$\overline{\text { D3 }}$} & 209 & 09 & 200 & \multirow{3}{*}{239.67} & \multirow{3}{*}{34.385} & \multirow{3}{*}{19.852} \\
\hline & 269 & 11 & 258 & & & \\
\hline & 415 & 154 & 261 & & & \\
\hline \multirow[t]{3}{*}{ D4 } & 389 & 03 & 386 & \multirow{3}{*}{313.00} & \multirow{3}{*}{71.547} & \multirow{3}{*}{41.308} \\
\hline & 249 & 06 & 243 & & & \\
\hline & 311 & 01 & 310 & & & \\
\hline
\end{tabular}

Table 2. Effect of D1 (nimbādi dhūpa), D2 (kumārāgāra dhūpa), D3 (daśāmiga dhūpa) \& D4 (gaṇa dhūpa) on B1 (S.aureus) after fumigation for $20 \mathrm{~min}$

One-way Analysis of Variance (ANOVA)

\begin{tabular}{|c|c|c|c|c|c|}
\hline Comparison & Degree of Freedom & $\begin{array}{c}\text { Sum of } \\
\text { Squares }\end{array}$ & $\begin{array}{c}\text { Mean of } \\
\text { Squares }\end{array}$ & F & p \\
\hline Between Groups & 3 & 21083 & 7027.6 & \multirow{2}{*}{3.373} & \multirow{2}{*}{0.0751} \\
\hline Within Groups & 8 & 16665 & 2083.2 & \\
\hline
\end{tabular}


Fig.1 Effect of fumigation with D1, D2, D3 and D4 in terms of $\%$ change in mean bacterial colony count of $S$. aureus.

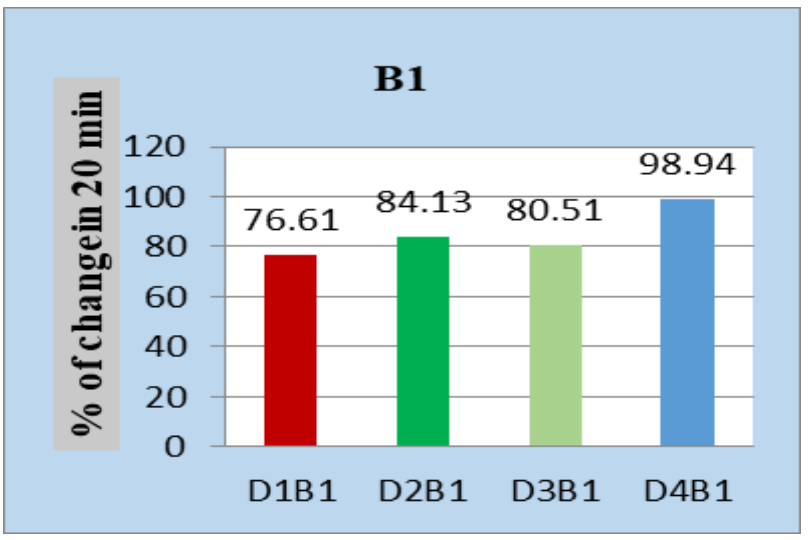

The \% change in mean colony count of B1 (S.aureus) after $20 \mathrm{~min}$ of fumigation was found to be $76.61 \%$ with drug D1, 84.13 \% with drug D2, $80.51 \%$ with drug D3 and $98.94 \%$ with drug D4. But intergroup comparison showed change in mean bacterial colony count was not significant statistically between various groups

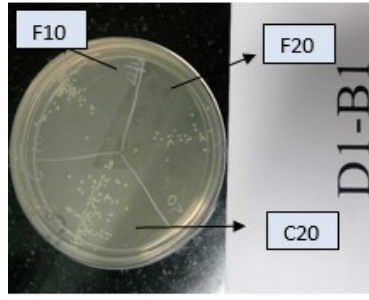

Fig.2 Fumigation by Nimbadi Dhupa on S.aureus

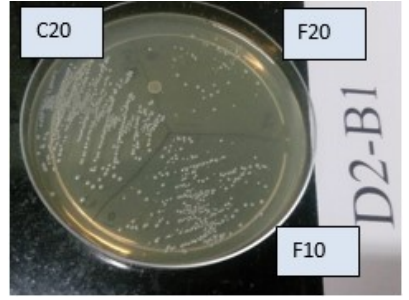

Fig.3 Fumigation by Kumaragara Dhupa on S.aureus

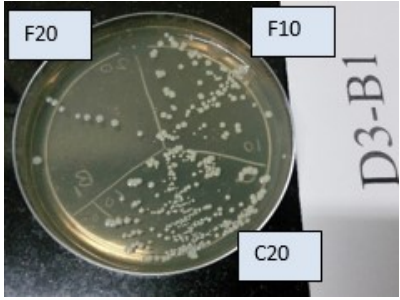

Fig.4 Fumigation by Dashanga Dhupa on S.aureus

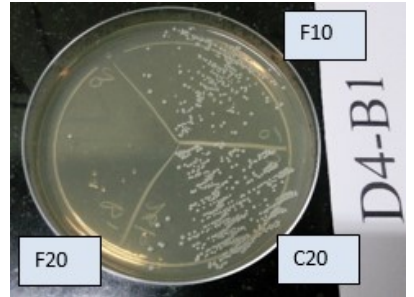

Fig.5 Fumigation by Gana Dhupa on S.aureus

\section{Discussion}

\section{Nimbadi Dhupa}

Fumigation for 20 min with this formulation resulted in remarkable difference of $76.61 \%$ in mean bacterial colony count of the experimental as compared with control group. The findings are supported by a previous study in which $93 \%$ sensitivity was seen with fumigation of neem leaves on S.aureus (6). Antimicrobial activity was found with extract form of various contents of Nimbadi Dhupa also. A study reported that the MIC of extract of Vaca rhizome was found to be $0.25 \mathrm{mg} / \mathrm{mL}$ for $S$. aureus with $1.62 \mathrm{~cm}$ zone of inhibition showing significant antibacterial activity (7). Nimbolide is also reported to have antibacterial activity against $S$. aureus and $S$. coagulase (8).

Results suggest that this drug formulation is having anti-microbial activity and is effective in reducing the bacterial load of S.aureus when administered through fumigation.

\section{Kumaragara Dhupa}

This formulation showed significant change in mean bacterial colony count after fumigation $(84.13 \%$ change in $20 \mathrm{~min}$ ). The contents of Kumaragara Dhupa possess good antimicrobial efficacy against S.aureus with their proven efficacy in earlier studies. Mishra et

al. reported the antimicrobial activity of aqueous and alcoholic extracts of asafoetida with MIC $6.25(\mathrm{mg} / \mathrm{ml})$ against S.aureus by agar well diffusion method.A. glauca oil exhibited variable degree of antimicrobial activity against $S$. aureus with the zone of inhibition of $22.8 \mathrm{~mm}$ and the lowest MIC values $159.3 \mu \mathrm{g} / \mathrm{Ml}$ (9). Hari Venkatesh K R et al. reported that the zone of inhibition by methanolic extract of Kasuki (Picrorhiza kurroa Royle ex Benth.) rhizome was $12 \mathrm{~mm}$ for $S$ aureus by well diffusion method.

Results of this experiment are in accordance with previous studies. This trial suggests that Kumaragara Dhupa has statistically significant anti-microbial activity on S.aureus when given in form of fumigation.

\section{Dashanga Dhupa}

A remarkable difference of $80.51 \%$ in mean bacterial colony count was observed after fumigation with this Dhupa for $20 \mathrm{~min}$. The drugs present in Dashanga Dhupa have well established antimicrobial activity against S.aureus as supported by earlier studies. Mohanta et al. found that the petroleum ether (PEE) and aqueous extract fractions (AQE) of Bhallataka showed inhibitory activity against $S$. aureus $(10 \mathrm{~mm})$ at $100 \mathrm{mg} /$ $\mathrm{ml}$. The chloroform fraction of Valeriana wallichi exhibiting significant activity against S.aureus was reported in a study (10). Sidgi Syed Anwer Hasson 
et al in a study found that $6000 \mu \mathrm{g} / \mathrm{ML}$ concentration of ethanol extract of was found to be bactericidal (11).

\section{Gana Dhupa}

Fumigation by Gana Dhupa on S.aureus showed a significant change in mean bacterial colony count after fumigation when compared with control group with \% change of $98.94 \%$ in 20 min fumigation. Many studies support the antimicrobial activity of contents of Gana Dhupa.

Laboratory studies have revealed that the honey is effective against methicillin resistant S.aureus MSA (12). Lusby PE et al conducted a research on manuka L. scoparium honey and found it to be effective against S.aureus (13). A Sabitha Rani et al reported that the MIC of extract of $V$ aca rhizome was found to be $0.25 \mathrm{mg} / \mathrm{mL}$ for $\mathrm{S}$. aureus with $1.62 \mathrm{~cm}$ zone of inhibition showing significant antibacterial activity.

Results suggest that slightly prolonged exposure of Dhupa will show better results.

\section{Conclusion}

Fumigation of D1 (Nimbadi Dhupa), D2 (Kumaragara Dhupa), D3 (Dashanga Dhupa) \& D4 (Gana Dhupa) on B1 (S.aureus) for $20 \mathrm{~min}$ when compared with control group shows that there was remarkable difference in mean bacterial colony. In Gana Dhupa change was $98.94 \%$ followed by $84.13 \%$ change with Kumaragara Dhupa, 80.51\% change with Dashanga Dhupa and $76.61 \%$ with Nimbadi Dhupa (Fig.1). Intergroup comparison showed change in mean bacterial colony count was not significant statistically between various groups but on the basis of results it can be inferred effectiveness of various Dhupa on S.aureus is in order of Gana Dhupa - Kumaragara Dhupa Dashanga Dhupa - Nimbadi Dhupa.

Thus Dhupana Karma can be used as add on therapy to oral antibiotics as it may reduce the dose along with enhancing the efficacy of the antibacterial therapy.

\section{References}

1. Mylotte JM, McDermott C, Spooner JA. Prospective study of 114 consecutive episodes of Staphylococcus aureus bacteremia. Rev. Infect. Dis. 1987;9:891-907.

2. Vrindamaadhava or Siddha Yoga, edited by Premvati tewari $1 / 429,1^{\text {st }}$ edition, Chaukambha Bharati Academy,2007, pg 58.

3. Agnivesha, Charaka, Dridhabala. Charaka Samhita, edited by Vaidya Yadavji Trikamji Acharya, Sarira Sthana, 8/61, Chaukhambha Publication, Varanasi, India, 2015, pg 352.

4. Vriddha Jeevaka, Kashyap samhita, edited by Hemraaj Sharma, kalpa sthana 1, Chaukhambha Sanskrit Series Office, Varanasi, India, 1953, pg 172.

5. Vriddha Jeevaka, Kashyap samhita, edited by Hemraaj Sharma, kalpa sthana 1, Chaukhambha Sanskrit Series Office, Varanasi, India, 1953,pg 171.

6. Mhaske Rajesh Harishchandra et al, Study Of Krimighna Effect Of Nimb ( Azadirachta Indica A.Juss.) Patra As Rakshoghna Dhoopan By Culture And Sensitivity Method W.S.R. To Pyogenic Bacteria, IRJP, 2012, 3 (6), 142-146.

7. Sabitha Rani et al, Evaluation of Antibacterial Activity from Rhizome Extract of Acorus calamus Linn, Journal of Scientitic \& Industrial Research, June 2003,Vol. 62., pg 623-625

8. Rojanapo $\mathrm{W}$ et al, Screening of antioxidants from some Thia vegetables and herbs. J. Sci. Thailand. 1985; 11: 177-188

9. Muhammad Irshad et al, Antioxidant, Antimicrobial and Phytotoxic Activities of Essential Oil of Angelica glauca, Asian Journal of Chemistry; (2011),Vol. 23, No. 5, 1947-1951.

10.Khuda F, Antimicrobial and antiinflammatory activities of leaf extract of Valeriana wallichii DC. Pak J Pharm Sci. 2012 Oct;25 (4):7159.

11.Sidgi Syed Anwer Hasson et al, Evaluation of antiresistant activity of Auklandia (Saussurea lappa) root against some human pathogens, Asian Pac J Trop Biomed. 2013 July; 3(7): 557-562.

12.Allen L, Hutchinson, Molan PC. The potential for us ing honey to treat wounds infected with MSA and VRE. First World Healing Congress, Melbourne, Au stralia. .

13.Lusby PE, Coombes AL,Wilkinson JM. bactericidal activity of different honeys against pathogenic bacter ia. Arch Med Res.2005;36:464-467. 